\title{
Effect of $\beta$-hydroxybutyric acid, parity, and body condition score on phenotype and proliferative capacity of colostral mononuclear leukocytes of high-yielding dairy cows
}

\author{
V. Meganck, ${ }^{* 1}$ B. M. Goddeeris, †‡ S. De Campeneere,§ M. Hostens, ${ }^{*}$ M. Van Eetvelde, ${ }^{*}$ S. Piepers, ${ }^{*}$ E. Cox, $\dagger$ \\ and G. Opsomer* \\ *Faculty of Veterinary Medicine, Department of Obstetrics, Reproduction and Herd Health, and \\ †Faculty of Veterinary Medicine, Laboratory of Immunology, University of Ghent, 9820 Merelbeke, Belgium \\ †Faculty of Bioscience Engineering, Department of Biosystems, KU Leuven, 3001 Heverlee, Belgium \\ §Institute for Agricultural and Fisheries Research, Animal Sciences Unit, ILVO, 9090 Melle, Belgium
}

\begin{abstract}
In neonatal calves, the ingestion of colostrum is imperative for preventing infectious diseases. Investigations into the transfer of passive immunity of cattle have primarily focused on the importance of colostral immunoglobulins, with a recent increase in focus on understanding the role of colostral leukocytes. The main objective of the present study was to measure the influence of parity, body condition score, serum nonesterified fatty acids, and serum $\beta$-hydroxybutyrate concentrations of periparturient cows on phenotype and mitogen- and antigen-induced proliferative capacity of bovine colostral leukocytes. Holstein-Friesian cows $(\mathrm{n}=141)$ were intramuscularly vaccinated at 60 and $30 \mathrm{~d}$ before the expected parturition date with a tetanus toxoid vaccine. Of these 141 animals, 28 primiparous and 72 multiparous cows were sampled immediately after parturition. Colostrum mononuclear cell populations were identified by flow cytometry using bovine cluster of differentiation markers, and the proliferative capacity of these cells was determined using a ${ }^{3} \mathrm{H}$-thymidine proliferation assay. Under-conditioned cows had a significantly higher percentage of colostral macrophages than normal-conditioned animals, whereas over-conditioned cows had significantly more colostral B-lymphocytes. Serum $\beta$-hydroxybutyrate was significantly associated with higher numbers of colostral T-lymphocytes and macrophages. Heifers had significantly higher mitogen- and antigen-induced proliferation of their colostral leukocytes than third parity or older cows. In conclusion, body condition score, parity, and serum $\beta$-hydroxybutyrate concentration of periparturient high-yielding dairy cows were shown to influence the number of colostral macrophages or the
\end{abstract}

Received August 25, 2014.

Accepted May 25, 2015.

${ }^{1}$ Corresponding author: vanessa.meganck@dvam.be mitogen- and antigen-induced proliferation of colostral leukocytes, possibly influencing the cellular immunity of the newborn calf.

Key words: colostrum, dairy cows, leukocytes, negative energy balance

\section{INTRODUCTION}

Investigations into the transfer of passive immunity of cattle have primarily focused on the importance of colostral immunoglobulins, but currently increasing attention is being given to other humoral and cellular components in colostrum (Hagiwara et al., 2000; Donovan et al., 2007). Bovine colostral leukocytes (CL) are mainly composed of neutrophils, macrophages, and lymphocytes (Duhamel et al., 1987). Uptake of these CL through the intestinal barrier has been shown in cattle, with a preferential route of uptake through the follicle-associated epithelium of Peyer's patches (Liebler-Tenorio et al., 2002). The functional importance of bovine CL is not yet fully understood, but they seem to enhance lymphocyte responses (Reber et al., 2005; Donovan et al., 2007), increase phagocytosis and bacterial-killing ability (Riedel-Caspari and Schmidt, 1991), and stimulate humoral immune responses in the neonatal calf (Riedel-Caspari, 1993).

The concentration of colostral immunoglobulins in the bovine species is known to be affected by breed (Tyler et al., 1999), parity (Moore et al., 2005; Morin et al., 2010), yield of colostrum at first milking (Chigerwe et al., 2008; Morin et al., 2010), season (Gulliksen et al., 2008), and the interval between parturition and first milking (Moore et al., 2005; Morin et al., 2010). In contrast, few articles have described factors affecting the phenotype or proliferative capacity of lymphocytes in bovine colostrum. Moreover, when describing CL, most manuscripts emphasize the importance of CL on cow mammary gland immunity and not on adoptive immunity transfer to the newborn (Park et al., 1993; 
Shafer-Weaver et al., 1996; Ohtsuka et al., 2010). Parity (Ohtsuka et al., 2010), infection state of the udder (Nonnecke and Harp, 1985; Park et al., 1993), and vitamin E and selenium supplementation (Wuryastuti et al., 1993) have been shown to influence the number or activation state of cow and sow mammary gland leukocytes (MGL). For example, CL of multiparous cows have a higher IFN- $\gamma$-to-IL-4 ratio than heifers (Ohtsuka et al., 2010) and the proliferative response of MGL is lower in infected than uninfected mammary glands (Nonnecke and Harp, 1985; Park et al., 1993). Furthermore, the proliferative response of MGL is generally lower than that of peripheral blood mononuclear cells (PBMC; Nonnecke and Harp, 1985; Harp and Nonnecke, 1986; Park et al., 1993). Also, high in vitro concentrations of NEFA and BHBA inhibit mitogen-induced proliferative responses and diminish DNA synthesis of PBMC (Franklin et al., 1991; Lacetera et al., 2004; Thanasak et al., 2005). Whether parity, BCS, serum NEFA, and serum BHBA concentrations of periparturient cows affect the function of bovine CL in vivo has, to the best of our knowledge, not been studied. The main objective of the present study was, therefore, to measure the effect of these variables on phenotype and mitogen- and antigen-induced proliferative capacity of bovine CL.

\section{MATERIALS AND METHODS}

The study was approved by the Ethical Committee of the Faculty of Veterinary Medicine, University of Ghent (EC2008/149).

\section{Herds, Animals, and Study Design}

An observational cross-sectional study design was used. Holstein-Friesian cows $(\mathrm{n}=141)$ were randomly selected from 17 commercial dairy herds in Flanders (Belgium; Figure 1). The herds had, on average, 59 lactating cows (range 36 to 95), and an average 305-d milk yield of $8,485 \mathrm{~kg}$ (range $=4,938-10,756 \mathrm{~kg}$ ). All 141 animals were intramuscularly vaccinated at 60 and $30 \mathrm{~d}$ before the expected parturition date with $2 \mathrm{~mL}$ of a tetanus toxoid vaccine (Tetapur, Merial Limited, Duluth, GA). The vaccine was chosen because tetanus is not a disease commonly vaccinated against in Belgium and because tetanus toxoid is a well-known strong inducer of humoral and cellular immunity. A pretest performed on 3 vaccinated cows (versus 3 nonvaccinated cows) showed the vaccine to perform well in terms of eliciting a strong cellular immune response. Of those 141 cows, 41 cows were excluded from the study due to various reasons: culling $(\mathrm{n}=6)$, abortion $(\mathrm{n}=$ $3)$, missed parturitions $(\mathrm{n}=22)$, leaking of colostrum prepartum $(\mathrm{n}=3)$, or parturition before administration of booster vaccination $(\mathrm{n}=7$; Figure 1$)$.

\section{Data and Sample Collection}

To isolate colostrum mononuclear cells (CMC), colostrum $(360 \mathrm{~mL})$ was sampled aseptically during the first milking postpartum $(90 \mathrm{~mL}$ from each individual quarter, composite sample). Following colostrum collection, the SCC was determined using a DeLaval

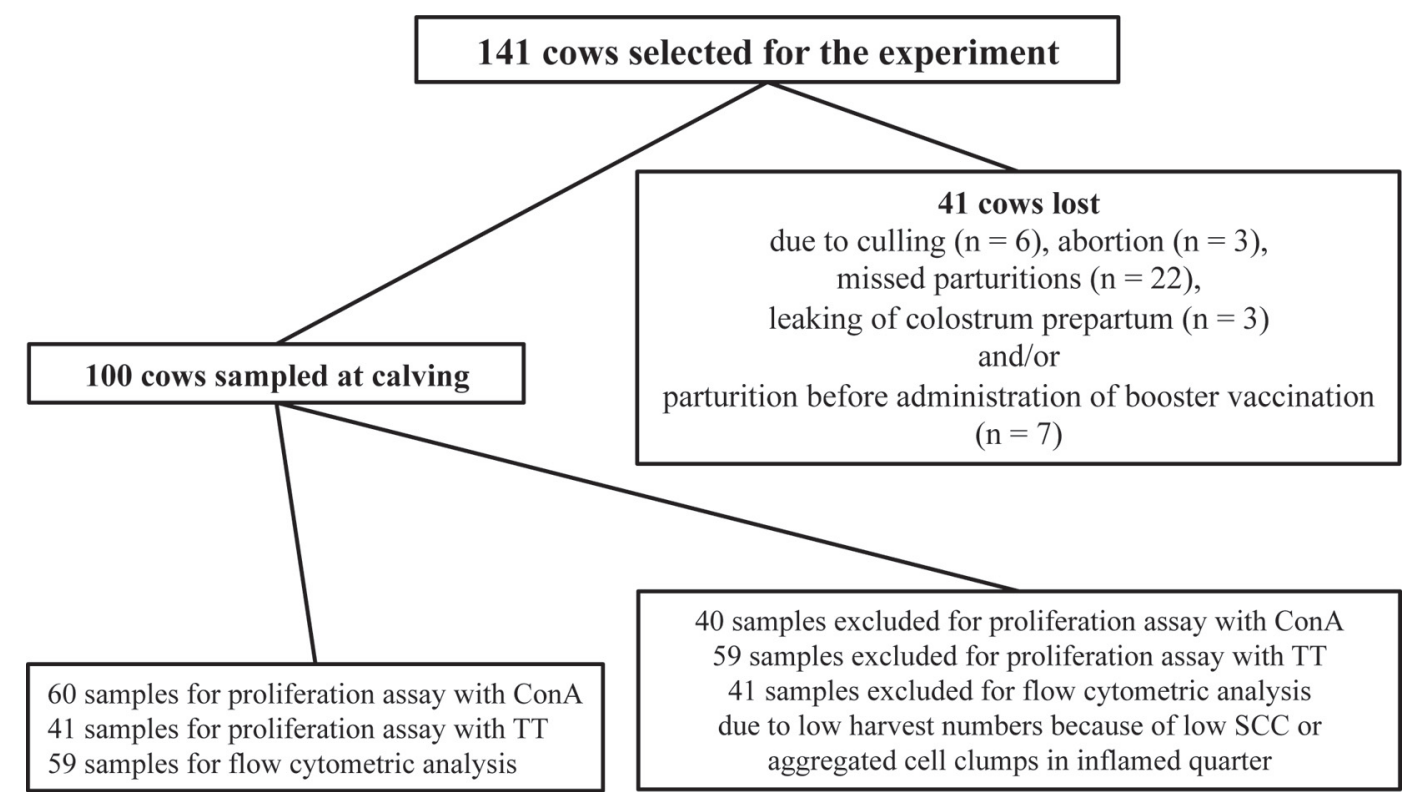

Figure 1. Flow of study subjects throughout the trial. ConA = concanavalin A; TT = tetanus toxoid. 
cell counter (DeLaval, Tumba, Sweden). All colostral samples were processed within $24 \mathrm{~h}$ after collection and stored on ice.

Parity and BCS were recorded at the moment of parturition. Cows were divided in 3 classes based on their parity: (1) heifers $(\mathrm{n}=28),(2)$ second parity $(\mathrm{n}=39)$, and (3) third parity or older $(\mathrm{n}=33)$. Body condition score was recorded by the same person immediately after parturition. Body condition score was expressed on a 5 -point scale with 0.25 increments as described by Edmonson et al. (1989). Cows were divided in 3 classes based on their BCS: (1) under-conditioned, $<3$; (2) normal condition, 3 to 3.5 ; and (3) over-conditioned, $>3.5$.

To determine NEFA and BHBA serum concentrations, all cows were blood-sampled immediately postpartum. Animals were tethered in headlocks and were approached by the researcher as calmly as possible to avoid any stress. Immediately after parturition, blood samples were taken from the coccygeal vein via (a) 2 tubes containing EDTA as an anticoagulant (Venosafe, Terumo Europe NV, Leuven, Belgium) to isolate PBMC as described below and (b) 1 silicone-coated tube (Venosafe) to quantify NEFA and BHBA. All samples except the EDTA tubes were centrifuged $(2,460 \times g$, $20 \mathrm{~min}, 7^{\circ} \mathrm{C}$ ) immediately after collection; serum was subsequently collected and frozen $\left(-80^{\circ} \mathrm{C}\right)$ until further analysis. Both NEFA and BHBA were analyzed using an automated colorimetric analyzer (Konelab $20 \mathrm{XT}$ Clinical Chemistry Analyzer, Thermo Scientific Inc., Waltham, MA) at the Animal Health Service Flanders (Drongen, Belgium). All herd visits were performed between July 2009 and May 2011.

\section{Isolation of PBMC}

The protocol was modified from a previously developed protocol (Goddeeris et al., 1986). Fifteen milliliters of EDTA-blood was diluted into an equal volume of Alsever's solution (Sigma-Aldrich, Diegem, Belgium) and layered over $20 \mathrm{~mL}$ of Lymfoprep (specific gravity $=1.077$; Axis-Shield, Oslo, Norway) in 50-mL conical tubes (BD Falcon, Becton Dickinson, Franklin Lakes, $\mathrm{NJ})$ and centrifuged $\left(30 \mathrm{~min}, 900 \times g, 18^{\circ} \mathrm{C}\right)$. Cells at the interface were aspirated, transferred to new 50$\mathrm{mL}$ conical tubes and washed with ice-cold Alsever's solution, containing 1\% fetal bovine serum (Greiner Bio One, Wemmel, Belgium; $10 \mathrm{~min}$ at $450 \times \mathrm{g}$ followed by $10 \mathrm{~min}$ at $300 \times g, 4^{\circ} \mathrm{C}$ ). The resulting cell pellets were resuspended in $1 \mathrm{~mL}$ of RPMI 1640 medium (Sigma-Aldrich), containing 10\% FBS, $2 \mathrm{mM}$ L-glutamine (Gibco, Life Technologies, Carlsbad, CA), $50 \mu \mathrm{g} / \mathrm{mL}$ of gentamicin (Sigma-Aldrich), and $5 \times 10^{-5}$ $M$ 2-mercaptoethanol (Merck, Darmstadt, Germany; hereafter named culture medium). The isolated PBMC were counted in a Neubauer counting chamber using eosin-nigrosin.

\section{Isolation of CMC}

Isolation of $\mathrm{CMC}$ was performed as described in Meganck et al. (2014). Briefly, diluted colostrum samples were centrifuged $\left(600 \times \mathrm{g}, 15 \mathrm{~min}, 18^{\circ} \mathrm{C}\right)$, the cream layer was removed, and cell pellets were washed twice. Cell pellets were then resuspended and over-layered onto $20 \mathrm{~mL}$ of Ficoll-Paque premium (GE Healthcare, Barrington, IL) followed by centrifugation $(900 \times g$, $\left.30 \mathrm{~min}, 18^{\circ} \mathrm{C}\right)$. Cells at the interface were aspirated and washed twice $\left(4^{\circ} \mathrm{C}\right)$. The resulting cell pellets were resuspended in $1 \mathrm{~mL}$ of culture medium. The isolated CMC were counted in a Neubauer counting chamber using eosin-nigrosin. Due to a poor yield of CMC, data of only 60 animals could be used to perform the proliferation assay with concanavalin A (ConA), of 41 animals to perform the proliferation assay with tetanus toxoid (TT), and of 59 animals to perform the flow cytometric assay (Figure 1). These relatively low yields were caused by low SCC or aggregated cell clumps in case of clinical mastitis.

\section{Leukocyte Phenotypic Analysis by Flow Cytometry}

The flow cytometric analysis was performed as described in Meganck et al. (2014). Monoclonal antibodies used were mouse anti-bovine cluster of differentiation (CD) 21 (MCA1424G, AbDSerotec, Puchheim, Germany) for B-lymphocytes; mouse anti-bovine CD2 (BAQ95A, VMRD, Pullman, WA), expressed on T-lymphocytes and NK-cells; and mouse anti-bovine CD14 (MM61A, VMRD) for monocytes or macrophages. Alexa Fluor 647-conjugated donkey anti-mouse IgG (H+L; Invitrogen, Life Technologies) was used as secondary antibody. Propidium iodide (Sigma-Aldrich) was used as a marker for dead cells. Ten thousand events per sample were acquired and relative numbers of cells positive for propidium iodide, CD2, CD21, and CD14 determined with FACSDiva Software (Becton Dickinson). Gating of the cells was performed, based on cell size (forward scatter), cellular granularity (side scatter), and fluorescence (FL-2 and FL-5 channels).

\section{Cellular Immune Response by ${ }^{3} \mathrm{H}$-Thymidine Proliferation Assay}

Cells were cultured in plain medium as a negative control for background proliferation, in the presence of $5 \mu \mathrm{g} / \mathrm{mL}$ of ConA (Sigma-Aldrich) as a positive control for mitogen-induced proliferation, or in the presence of 
various concentrations of purified TT (kindly provided by Merial Limited) for antigen-induced proliferation. The optimal stimulating concentration was used for further analysis (10 flocculation units $/ \mathrm{mL}=33.6 \mu \mathrm{g} /$ $\mathrm{mL}$ ). All wells contained $2 \times 10^{5}$ cells in a final volume of $200 \mu \mathrm{L}$ and all added substances were performed in triplicate. Cells were incubated for 3 (medium, ConA) or $5 \mathrm{~d}(\mathrm{TT})$ at $37^{\circ} \mathrm{C}$ in a humidified atmosphere containing $5 \% \mathrm{CO}_{2}$. Cells were pulse-labeled for $18 \mathrm{~h}$ with $1 \mu \mathrm{Ci}$ of ${ }^{3} \mathrm{H}$-thymidine per well and harvested on glass fiber filters (Whatman, GE Healthcare), then radioactivity was measured using a Beckman $\beta$-scintillation counter (Beckman, Suarlée, Belgium). Data were acquired as counts per minute (CPM). Mitogen-induced proliferation in $\mathrm{CMC}$ is reported as $\mathrm{CPM}$ of $\mathrm{CMC}$ stimulated with ConA ( $\left.\mathbf{C P M}_{\mathbf{C M C C o n A}}\right)$ and antigeninduced proliferation in $\mathrm{CMC}$ is reported as $\mathrm{CPM}$ of CMC stimulated with TT $\left(\mathbf{C P M}_{\mathbf{C M C T T}}\right)$.

\section{Statistical Analysis}

The distribution of all dependent variables was checked for normality and eventually data were transformed to approximate the Gaussian distribution. All CPM data and flow cytometric data for colostrum were therefore log-transformed before further analysis. Descriptive statistics were done using PROC MEANS and PROC FREQ of SAS v9.4 (SAS Institute Inc., Cary, $\mathrm{NC})$.

To determine the associations between parity, body condition of cows, NEFA and BHBA serum concentrations, and $\mathrm{CPM}_{\mathrm{CMCConA}}$, $\mathrm{CPM}_{\mathrm{CMCTT}}$, percentage of $\mathrm{CD} 2^{+} \mathrm{CMC}$, percentage of $\mathrm{CD} 21^{+} \mathrm{CMC}$, and percentage of $\mathrm{CD} 14^{+} \mathrm{CMC}$, linear regression models with parity, BCS, BHBA, and NEFA concentrations measured immediately postpartum as independent variables of main interest were tested (PROC GLIMMIX). Herd was tested as a random factor, but the covariance parameter estimate was negligible and further inclusion of the variable herd was not needed. Initially, separate associations were tested between the outcome variables $\mathrm{CPM}_{\mathrm{CMCConA}}, \mathrm{CPM}_{\mathrm{CMCTT}}, \mathrm{CD}^{+} \mathrm{CMC}$, and $\mathrm{CD} 14^{+}$ $\mathrm{CMC}$ and all independent variables mentioned above. Statistical significance in these univariate univariable models was assessed at $P<0.20$. Second, Pearson cor- relation coefficients were calculated among the significant independent variables using the CORR procedure in SAS v9.4 to check for multicollinearity. If 2 independent variables had a correlation coefficient $\geq 0.6$, only one was selected for further analysis. In the third step, a univariate multivariable or univariable model was fit. Statistical significance was assessed at $P<0.05$.

To compare CPM of CMC and PBMC, and to identify differences between leukocyte phenotype of CMC and PBMC, separate one-way ANOVA tests were performed in SAS v9.4 for $\mathrm{CD}^{+}$and $\mathrm{CD}^{+} 4^{+}$cells and for TT-induced proliferation and separate nonparametric ANOVA tests (Wilcoxon signed-rank test) were performed for the CD21 $1^{+}$cells and for the ConA-induced proliferation. Significance was assessed at $P<0.05$.

\section{RESULTS}

\section{Descriptive Statistics}

Descriptive statistics on SCC and isolation of PBMC and CMC can be found in Table 1. Descriptive statistics for the leukocyte phenotypic analysis by flow cytometry and for the cellular immune response by ${ }^{3} \mathrm{H}-$ thymidine proliferation assay can be found in Table 2 .

\section{Leukocyte Phenotypic Analysis by Flow Cytometry}

Only BHBA was significantly associated with the percentage of $\mathrm{CD} 2{ }^{+} \mathrm{CMC}$. The higher the BHBA serum concentration, the higher $(P=0.049)$ the percentage of $\mathrm{CD}^{+} \mathrm{CMC}$ (Table 3). Only BCS was significantly associated with the percentage of $\mathrm{CD} 21^{+} \mathrm{CMC}$. Overconditioned cows (BCS >3.5) had significantly $(P=$ 0.006) more $\mathrm{CD} 21^{+} \mathrm{CMC}$ than normal-conditioned cows: 4.04 vs. $1.37 \%$, respectively (BCS 3-3.5; Table 4).

A first reduction based on the univariable associations revealed all 4 variables (parity, BCS, NEFA, and BHBA) to be associated with CD $14^{+}$CMC. None of the parameters were correlated with each other $(\mathrm{r}=$ $-0.06-0.13 ; P \geq 0.218$ ). In the final multivariable model, under-conditioned cows $(\mathrm{BCS}<3)$ had more $(P=$ $0.008) \mathrm{CD}^{+} 4^{+} \mathrm{CMC}$ than normal-conditioned animals (BCS 3-3.5): 40.25 vs. $25.88 \%$, respectively (Table 5, Figure 2). Also, the higher the BHBA serum concentra-

Table 1. Descriptive statistics on SCC and isolation of peripheral blood mononuclear cells (PBMC) and colostrum mononuclear cells (CMC) based on 100 cows

\begin{tabular}{lccc}
\hline Variable & Mean & Median & IQR $^{1}$ \\
\hline Isolated PBMC (cells/mL of blood) & $7.7 \times 10^{6}$ & $4.3 \times 10^{6}$ & $1.5 \times 10^{6}-9.7 \times 10^{6}$ \\
Colostral SCC (cells/mL of colostrum) & $1.2 \times 10^{6}$ & $6.9 \times 10^{5}$ & $2.1 \times 10^{5}-1.3 \times 10^{6}$ \\
Isolated CMC (cells/mL of colostrum) & $1.2 \times 10^{5}$ & $3.2 \times 10^{4}$ & $6.3 \times 10^{3}-1.3 \times 10^{5}$ \\
\hline
\end{tabular}

${ }^{1} \mathrm{IQR}=$ interquartile range. 
Table 2. Descriptive statistics for the phenotypic analysis by flow cytometry for the cellular immune response by the ${ }^{3} \mathrm{H}$-thymidine proliferation assay

\begin{tabular}{|c|c|c|c|c|c|c|c|c|}
\hline Protocol & \multicolumn{4}{|c|}{ Peripheral blood mononuclear cells } & \multicolumn{4}{|c|}{ Colostral mononuclear cells } \\
\hline $\mathrm{CD}^{+}+$ & 65 & $32^{\mathrm{a}}$ & 33 & $26-41$ & 49 & $16^{\mathrm{b}}$ & 10 & $3-23$ \\
\hline $\mathrm{CD} 21^{+}$ & 56 & $25^{\mathrm{a}}$ & 26 & $20-28$ & 41 & $2.0^{\mathrm{b}}$ & 0.9 & $0.3-2.5$ \\
\hline $\mathrm{CD} 14^{+}$ & 72 & $15^{\mathrm{a}}$ & 14 & $9-20$ & 59 & $28^{\mathrm{b}}$ & 24 & $11-43$ \\
\hline Medium & 90 & $6^{\mathrm{a}}$ & 1 & $0-3$ & 60 & $15^{\mathrm{b}}$ & 4 & $1-14$ \\
\hline Concanavalin A & 90 & $321^{\mathrm{a}}$ & 346 & $176-425$ & 60 & $86^{\mathrm{b}}$ & 15 & $6-56$ \\
\hline Tetanus toxoid & 51 & 15 & 1 & $0-14$ & 41 & 22 & 4 & $0-14$ \\
\hline
\end{tabular}

$\overline{\mathrm{a}, \mathrm{b}}$ Values within a row with different superscript letters are significantly different $(P<0.01)$.

${ }^{1} \mathrm{IQR}=$ interquartile range.

${ }^{2} \mathrm{CD} 2^{+}=$cluster of differentiation 2, recognizes T-lymphocytes; CD21 ${ }^{+}=$cluster of differentiation 21 , recognizes B-lymphocytes; CD14 ${ }^{+}=$ cluster of differentiation 14, recognizes macrophages/monocytes; PI = propidium iodide, recognizes dead cells.

${ }^{3} \mathrm{CPM}=$ counts per minute.

tion, the higher the percentage of $\mathrm{CD} 14^{+} \mathrm{CMC}(P=$ 0.023 ; Table 5). On average, lymphocyte percentages were lower $(P<0.001)$ in colostrum compared with blood, whereas the opposite was found for macrophages or monocytes (Table 2).

\section{Cellular Immune Response by ${ }^{3} \mathrm{H}$-thymidine Proliferation Assay}

A first reduction based on the univariable associations and highly correlated variables revealed only 1 variable (parity) to be associated with $\mathrm{CPM}_{\mathrm{CMCConA}}$. Heifers had significantly higher CMC mitogen-induced proliferation than second $(P=0.049)$ or third parity or older cows: $1.9 \times 10^{5}$ vs. $1.3 \times 10^{4}$ vs. $7.4 \times 10^{4} \mathrm{CPM}$, respectively $(P=0.006$; Figure 3 , Table 6$)$.

A first reduction based on the univariable associations revealed only 1 variable (parity) to be associated with $\mathrm{CPM}_{\text {СмСтт. Heifers had higher }(P=0.045) \mathrm{CMC}}$ antigen-induced proliferation than third parity or older cows: $4.4 \times 10^{4}$ vs. $1.3 \times 10^{4} \mathrm{CPM}$ (Figure 4 , Table 6).

The mean background proliferation in PBMC was lower $(P<0.001)$ than that in CMC (Table 2). The mean $\mathrm{PBMC}$ mitogen-induced proliferation was higher $(P<0.001)$ than that of the CMC (Table 2$)$. The mean

Table 3. Final univariate univariable model for the log-transformed percentage of colostral CD2 ${ }^{+}$leukocytes using data of 48 animals

\begin{tabular}{lcccc}
\hline Predictor & $\begin{array}{c}\text { Estimate } \\
(\log \%)\end{array}$ & $\begin{array}{c}\text { No. of } \\
\text { samples }\end{array}$ & SE & $P$-value \\
\hline Intercept & 0.89 & 48 & 0.59 & 0.137 \\
BHBA & 1.57 & 48 & 0.78 & 0.049 \\
\hline
\end{tabular}

antigen-induced proliferation for the PBMC was practically equal $(P=0.382)$ to that of the CMC (Table 2$)$.

\section{DISCUSSION}

The main objective of the present study was to measure the effect of parity, BCS, serum NEFA, and serum BHBA concentrations on phenotype and mitogen- and antigen-induced proliferative capacity of bovine CL. Fat cows have large amounts of adipose tissue, and in times of energy deficiency this over-condition is linked with adverse health effects (Goff, 2006). Blood mononuclear leukocytes isolated from over-conditioned cows secreted less IFN- $\gamma$ than those of thin and medium cows $1 \mathrm{wk}$ before the expected parturition date. In the present study, BCS of periparturient cows had a significant effect on the number of B-lymphocytes and macrophages resident in colostrum. The proposed causal relationship of Collard et al. (2000), that thin cows or cows in severe negative energy balance may be more susceptible to infection, could explain our findings.

High-yielding dairy cows are known to have an impaired immunity in early lactation compared with the

Table 4. Final univariate univariable model for the log-transformed percentage of colostral CD $21^{+}$leukocytes using data of 35 animals

\begin{tabular}{|c|c|c|c|c|}
\hline Predictor & $\begin{array}{c}\text { Estimate } \\
(\log \%)\end{array}$ & $\begin{array}{c}\text { No. of } \\
\text { samples }\end{array}$ & $\mathrm{SE}$ & $P$-value \\
\hline $\begin{array}{l}\text { Intercept } \\
\mathrm{BCS}^{1}\end{array}$ & -0.08 & 48 & 0.23 & 0.726 \\
\hline $\begin{array}{l}<3 \\
3-35\end{array}$ & $\begin{array}{c}0.19 \\
\text { Beference }\end{array}$ & $\begin{array}{r}6 \\
21\end{array}$ & 0.49 & 0.695 \\
\hline $\begin{array}{l}3-3.5 \\
>3.5\end{array}$ & $\begin{array}{c}\text { Reference } \\
1.30\end{array}$ & $\begin{array}{r}21 \\
8\end{array}$ & 0.44 & 0.006 \\
\hline
\end{tabular}

${ }^{1}$ Measured at the day of parturition. 
Table 5. Final univariate multivariable model for the log-transformed percentage of colostral macrophages $\left(\mathrm{CMC}_{\mathrm{CD} 14}\right)$ using data of 57 animals

\begin{tabular}{|c|c|c|c|c|}
\hline Predictor & $\begin{array}{c}\text { Estimate } \\
(\log \%)\end{array}$ & $\begin{array}{c}\text { No. of } \\
\text { samples }\end{array}$ & SE & $P$-value \\
\hline Intercept & 2.21 & 57 & 0.31 & $<0.001$ \\
\hline $\mathrm{BHBA}^{1}$ & 0.96 & 57 & 0.41 & 0.023 \\
\hline $\mathrm{BCS}^{1}$ & & & & 0.028 \\
\hline$<3$ & 0.85 & 8 & 0.31 & 0.008 \\
\hline $3-3.5$ & Reference & 39 & & \\
\hline$>3.5$ & 0.22 & 10 & 0.28 & 0.439 \\
\hline
\end{tabular}

${ }^{1}$ Measured on the day of parturition.

mid- to late lactation period, and are therefore more susceptible to all kinds of infections during the periparturient period (Ishikawa, 1987; Kehrli et al., 1989a,b). This impaired immunity explains the relatively low CMC mitogen- and antigen-induced proliferation found in the present and other studies (Concha et al., 1980; Archambault et al., 1988a; Kehrli et al., 1989a). In humans, increased plasma NEFA and oxidative stress are well known factors effecting systemic inflammation (Calder, 2008; Wood et al., 2009). Although neutrophils isolated from cows with high BHBA levels had a decreased respiratory burst activity (Opsomer et al., 1998;
Hoeben et al., 2000; Lacetera et al., 2005), the present study could not show a significant effect of BHBA nor NEFA on mitogen- and antigen-induced proliferation in CMC. The latter might be (partly) explained by the fact that the number of animals with high values, and thus expected to suffer from negative energy balance, was almost negligible. Conversely, serum BHBA was positively associated with colostral T-lymphocytes and macrophages. The latter results comply with the theory of the impaired immunity of cows caused by ketosis.

Parity was shown to have a significant effect on the mitogen- and antigen-induced proliferation of CMC. Older cows had lower mitogen- and antigen-induced $\mathrm{CPM}$ values than heifers. Studies investigating the effect of aging on immune function in humans have indicated a diminished role of type 1 cytokines, such as IFN- $\gamma$ and IL-2, which promote cell-mediated immunity (Alberti et al., 2006). This is in line with the results of the current study. Ohtsuka et al. (2010) found 2 contradictory phenomena: activation of colostral lymphocytes versus suppression of the systemic type 1 reaction in periparturient healthy cows. Cows in parity $\geq 4$ suffered from more profound periparturient impairment of neutrophil function than younger cows (Gilbert et al., 1993), again confirming the present results.

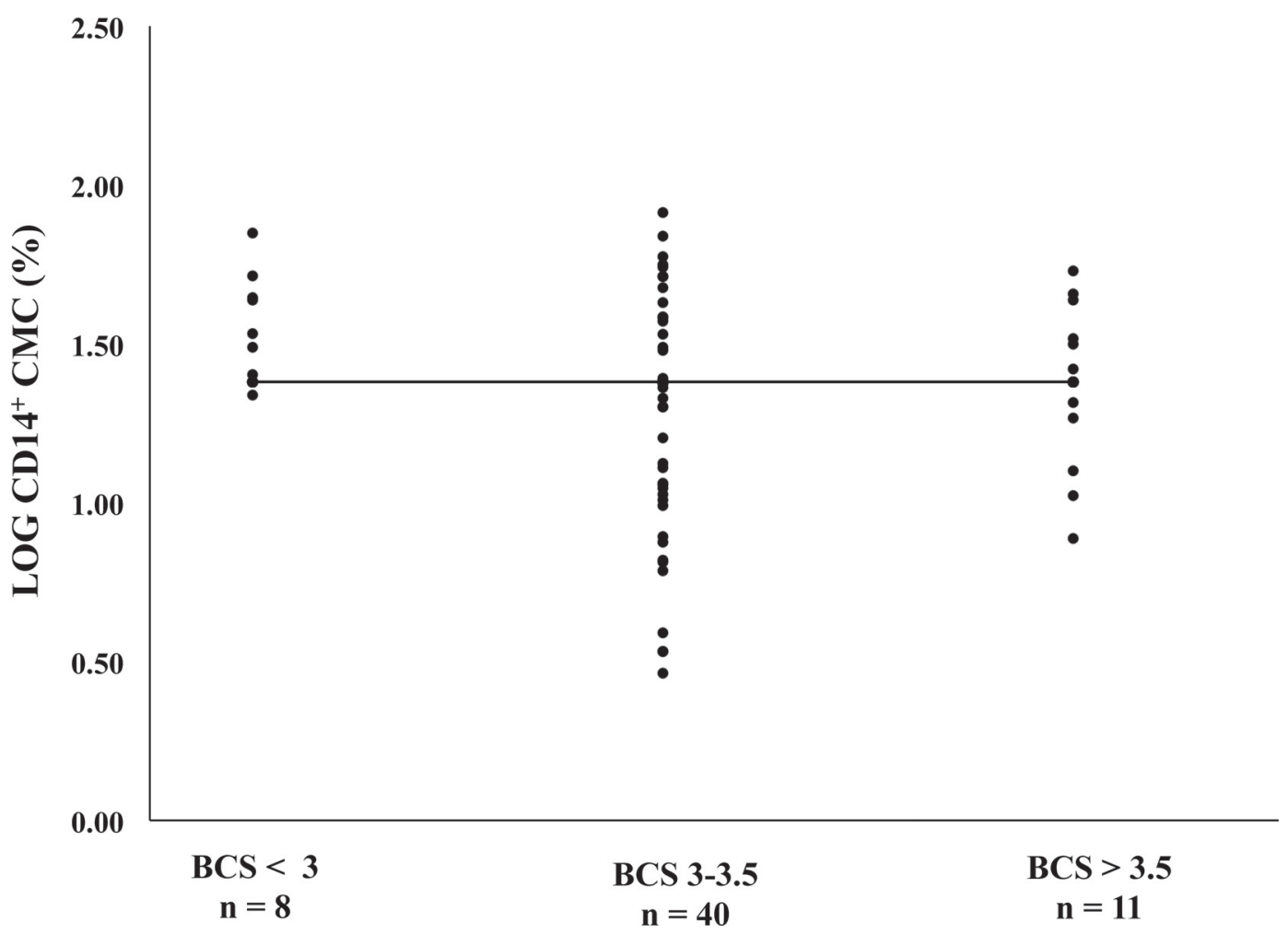

Figure 2. Under-conditioned cows $(\mathrm{BCS}<3$ ) had significantly more colostral macrophages than normal conditioned cows $(\mathrm{BCS} 3-3.5 ; P=$ 0.008). Results are represented as the raw logarithmic unmodeled data with the solid black line denoting the median value. $\mathrm{CD} 14^{+}=$cluster of differentiation 14; CMC = colostrum mononuclear cells. 
Table 6. Final univariate univariable model for the log-transformed counts per minute of colostral mononuclear cells stimulated with the mitogen concanavalin A (data of 60 animals) or tetanus toxoid (data of 41 animals)

\begin{tabular}{|c|c|c|c|c|c|c|c|c|}
\hline \multirow[b]{2}{*}{ Predictor } & \multicolumn{4}{|c|}{ Concanavalin A } & \multicolumn{4}{|c|}{ Tetanus toxoid } \\
\hline & $\begin{array}{c}\text { Estimate } \\
\left(\log \mathrm{CPM}^{1}\right)\end{array}$ & $\begin{array}{c}\text { No. of } \\
\text { samples }\end{array}$ & $\mathrm{SE}$ & $P$-value & $\begin{array}{c}\text { Estimate } \\
(\log C P M)\end{array}$ & $\mathrm{n}$ & $\mathrm{SE}$ & $P$-value \\
\hline Intercept & 10.89 & & 0.47 & $<0.001$ & 9.10 & 41 & 0.62 & $<0.001$ \\
\hline Parity & & & & 0.019 & & & & 0.104 \\
\hline Heifer & Reference & 16 & & & Reference & 14 & & \\
\hline 2nd parity & -1.25 & 27 & 0.59 & 0.049 & -1.35 & 17 & 0.83 & 0.113 \\
\hline
\end{tabular}

${ }^{1} \mathrm{CPM}=$ counts per minute.

In the present study, the mean percentages of CD2 ${ }^{+}$ and $\mathrm{CD} 14^{+} \mathrm{CMC}$ were comparable or lower than percentages found in previous studies (Park et al., 1992; Yang et al., 1997; Kiku et al., 2010). The mean percentage of $\mathrm{CD} 21^{+} \mathrm{CMC}$ was much lower than the percentage of B-lymphocytes found in bovine colostrum in other studies (Park et al., 1992; Kiku et al., 2010). Our results concerning B-lymphocytes agree with others (Taylor et al., 1994; Harp et al., 2004), as T-lymphocytes traffic selectively into bovine mammary gland secretions whereas B-lymphocytes represent a minor population as compared with peripheral blood. In general, the composition of the lymphoid compartment in the lac- tating mammary gland differs from that in peripheral blood, as demonstrated in the present and other studies (Park et al., 1992; Wirt et al., 1992; Van Kampen et al., 1999). Furthermore, the percentages of the different CMC subpopulations depend on differences in the techniques used to identify them (Prescott and Breed, 1910; Concha et al., 1980; Nonnecke and Kehrli, 1985), the gating strategy (Ohtsuka et al., 2010), the definition of colostrum (Archambault et al., 1988a), and the health status of the udder (Kiku et al., 2010).

Cell-mediated immunity was tested in vitro through mitogen- and antigen-induced proliferation of lymphocytes. Several research groups reported CMC to re-

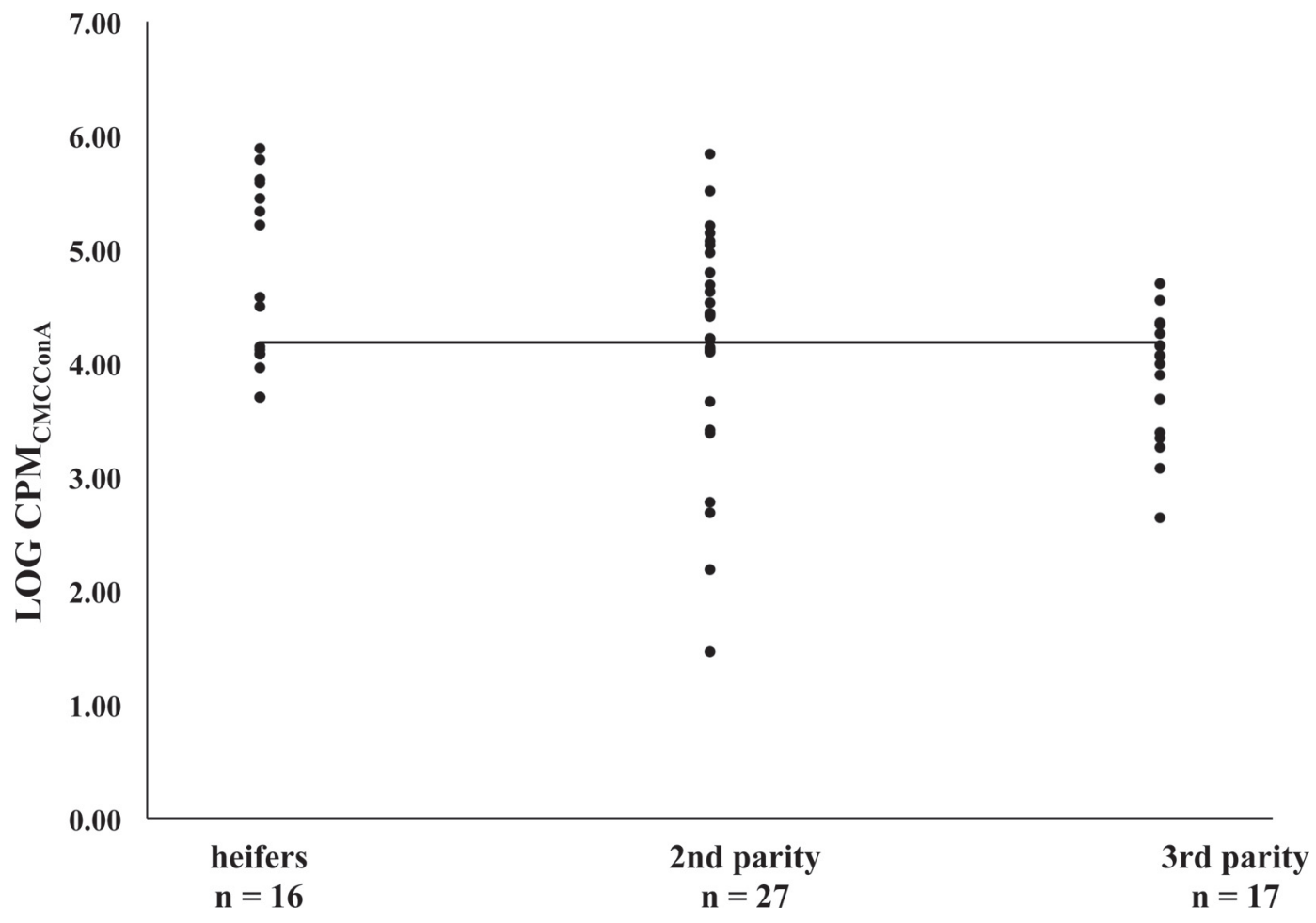

Figure 3. Heifers had significantly higher mitogen-induced proliferation of colostral mononuclear cells $\left(\mathrm{CPM}_{\mathrm{CMCConA}}\right)$ than second $(P=$ $0.049)$ and third parity or older cows $(P=0.006)$. Results are represented as the raw logarithmic unmodeled data with the solid black line denoting the median value. 
spond to mitogens and specific antigens (Archambault et al., 1988a,b). Background CPM are generally higher in MGL than in PBMC (Parmely et al., 1976; Concha et al., 1980; Nonnecke and Kehrli, 1985), as demonstrated in the current study. Specifically for CMC, this higher background CPM might be explained by the activating effects of colostrum on leukocytes (Sugisawa et al., 2001; Reber et al., 2006). Overall, MGL, both in cattle and in humans, seem not to react as strong as PBMC when confronted in vitro with mitogens and certain antigens (Parmely et al., 1976; Nonnecke and Harp, 1985; Park et al., 1993), as demonstrated in the present study for the mitogen ConA but not for the antigen TT. However, antigen-induced proliferation strongly depends on the antigen used (Smith and Goldman, 1968; Parmely et al., 1977; Archambault et al., 1988b). Various reasons can be proposed for the lower proliferation of MGL than PBMC: fewer $\mathrm{CD}^{+}$cells producing growth promoting cytokines (Shafer-Weaver et al., 1996), a higher percentage of $\mathrm{CD}^{+}$lymphocytes that have a suppressive effect (Park et al., 1993; ShaferWeaver et al., 1996; Asai et al., 2000), changes in other cell types such as macrophages (Goddeeris et al., 1986; Nickerson, 1989), or memory cell phenotype (Bertotto et al., 1990; Taylor et al., 1994). Testing various antigens is needed to study the possibility of vaccinating dams to protect the newborn via adoptive cellular immunity.

\section{CONCLUSIONS}

Increasing evidence demonstrates the relevance of viable lymphocytes in bovine colostrum. Most studies have focused on CL in terms of mastitis; however, the possible important role of CL as part of the adoptive immunity transfer to newborn calves should not be overlooked. Body condition score of periparturient cows had a significant effect on the number of macrophages and B-lymphocytes resident in colostrum. Furthermore, heifers had a significantly higher mitogen- and antigeninduced proliferation of CL compared with cows of third or higher parity. Also, serum BHBA concentration was significantly associated with higher numbers of colostral T-lymphocytes and macrophages. Further studies are warranted to deepen the knowledge concerning CL and to research possible adverse effects of negative energy balance in periparturient dairy cows on the adoptive immunity transfer to their neonatal calves.

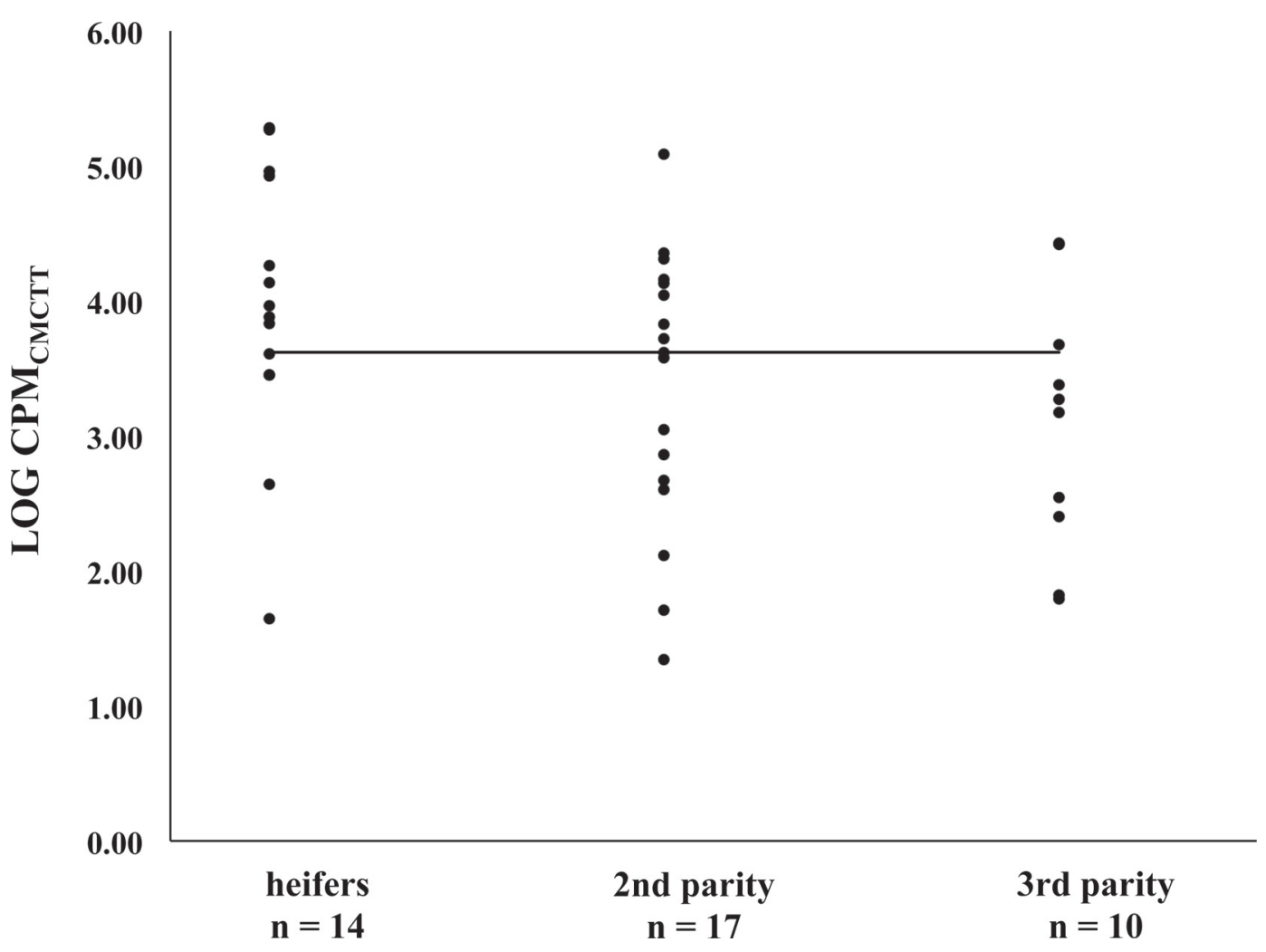

Figure 4. Heifers had significantly higher tetanus toxoid-induced proliferation of colostral mononuclear cells $\left(\mathrm{CPM}_{\mathrm{CMCTT}}\right)$ than third parity or older cows $(P=0.045)$. Results are represented as the raw logarithmic unmodeled data with the solid black line denoting the median value. 


\section{ACKNOWLEDGMENTS}

This study was funded by a $\mathrm{PhD}$ grant to $\mathrm{V}$. Meganck (no. 83216) by the Institute for the Promotion of Innovation through Science and Technology in Flanders (IWT Vlaanderen, Brussels, Belgium). We thank the owners of the enrolled farms for their cooperation. The authors also thank Merial (Duluth, GA) for kindly providing the tetanus toxoid peptide. A special word of thanks goes to Isabel Lemahieu, Lars Hulpio, and Petra Van Damme (all Department of Obstetrics, Reproduction, and Herd Health, University of Ghent, Merelbeke, Belgium) for their technical assistance in the laboratory.

\section{REFERENCES}

Alberti, S., E. Cevenini, R. Ostan, M. Capri, S. Salvioli, L. Bucci, L. Ginaldi, M. De Martinis, C. Franceschi, and D. Monti. 2006. Agedependent modifications of type 1 and type 2 cytokines within virgin and memory CD4+ T cells in humans. Mech. Ageing Dev. 127:560-566.

Archambault, D., G. Morin, and M. Elazhary. 1988a. Isolation of bovine colostral lymphocytes: in vitro blastogenic responsiveness to concanavalin A and bovine rotavirus. Ann. Rech. Vet. 19:169-174.

Archambault, D., G. Morin, Y. Elazhary, R. S. Roy, and J. H. Joncas. 1988b. Immune respons of pregnant heifers and cows to bovine rotavirus inoculation and passive protection to rotavirus infection in newborn calves fed colostral antibodies or colostral lymphocytes. Am. J. Vet. Res. 49:1084-1091.

Asai, K., Y. Komine, T. Kozutsumi, T. Yamaguchi, K. Komine, and K. Kumagai. 2000. Predominant subpopulations of T lymphocytes in the mammary gland secretions during lactation and intraepithelial $\mathrm{T}$ lymphocytes in the intestine of dairy cows. Vet. Immunol. Immunopathol. 73:233-240.

Bertotto, A., R. Gerli, G. Fabietti, S. Crupi, C. Arcangeli, F. Scalise, and R. Vaccaro. 1990. Human breast milk T lymphocytes display the phenotype and functional characteristics of memory $\mathrm{T}$ cells. Eur. J. Immunol. 20:1877-1880.

Calder, P. C. 2008. The relationship between the fatty acid composition of immune cells and their function. Prostaglandins Leukot. Essent. Fatty Acids 79:101-108.

Chigerwe, M., J. W. Tyler, J. R. Middleton, J. N. Spain, J. S. Dill, and B. J. Steevens. 2008. Comparison of four methods to assess colostral IgG concentration in dairy cows. J. Am. Vet. Med. Assoc. 233:761-766

Collard, B. L., P. J. Boettcher, J. C. M. Dekkers, D. Petitclerc, and L. R. Schaeffer. 2000. Relationship between energy balance and health traits of dairy cattle in early lactation. J. Dairy Sci. 83:2683-2690.

Concha, C., O. Holmberg, and B. Morein. 1980. Characterization and response to mitogens of mammary lymphocytes from the bovine dry-period secretion. J. Dairy Res. 47:305-311.

Donovan, D. C., A. J. Reber, J. D. Gabbard, M. Aceves-Avila, K. L. Galland, K. A. Holbert, L. O. Ely, and D. J. Hurley. 2007. Effect of maternal cells transferred with colostrum on cellular responses to pathogen antigens in neonatal calves. Am. J. Vet. Res. 68:778-782.

Duhamel, G. E., D. Bernoco, W. C. Davis, and B. I. Osburn. 1987. Distribution of $\mathrm{T}$ and B lymphocytes in mammary dry secretions, colostrum and blood of adult dairy cattle. Vet. Immunol. Immunopathol. 14:101-122.

Edmonson, A. J., I. J. Lean, L. D. Weaver, T. Farver, and G. Webster. 1989. A body condition scoring chart for Holstein dairy cows. J. Dairy Sci. 72:68-78.

Franklin, S. T., J. W. Young, and B. J. Nonnecke. 1991. Effects of ketones, acetate, butyrate, and glucose on bovine lymphocyte proliferation. J. Dairy Sci. 74:2507-2514.
Gilbert, R. O., Y. T. Grohn, P. M. Miller, and D. J. Hoffman. 1993 The effect of parity on peripartum neutrophil function in dairy cows. Vet. Immunol. Immunopathol. 36:75-82.

Goddeeris, B. M., C. L. Baldwin, O. ole-MoiYoi, and W. I. Morrison. 1986. Improved methods for purification and depletion of monocytes from bovine peripheral blood mononuclear cells: Functional evaluation of monocytes in responses to lectins. J. Immunol. Methods $89: 165-173$.

Goff, J. P. 2006. Major advances in our understanding of nutritiona influences on bovine health. J. Dairy Sci. 89:1292-1301.

Gulliksen, S. M., K. I. Lie, L. Sølverød, and O. Østerås. 2008. Risk factors associated with colostrum quality in Norwegian dairy cows. J. Dairy Sci. 91:704-712.

Hagiwara, K., S. Kataoka, H. Yamanaka, R. Kirisawa, and H. Iwai 2000. Detection of cytokines in bovine colostrum. Vet. Immunol. Immunopathol. 76:183-190.

Harp, J. A., and B. J. Nonnecke. 1986. Regulation of mitogenic responses by bovine milk leukocytes. Vet. Immunol. Immunopathol. 11:215-224.

Harp, J. A., T. E. Waters, and J. P. Goff. 2004. Lymphocyte subsets and adhesion molecule expression in milk and blood of periparturient dairy cattle. Vet. Immunol. Immunopathol. 102:9-17.

Hoeben, D., E. Monfardini, G. Opsomer, C. Burvenich, H. Dosogne, A. de Kruif, and J. F. Beckers. 2000. Chemiluminescence of bovine polymorphonuclear leucocytes during the periparturient period and relation with metabolic markers and bovine pregnancy-associated glycoprotein. J. Dairy Res. 67:249-259.

Ishikawa, H. 1987. Observation of lymphocyte function in perinatal cows and neonatal calves. Nihon Juigaku Zasshi 49:469-475.

Kehrli, M. E., B. J. Nonnecke, and J. A. Roth. 1989a. Alterations in bovine lymphocyte function during the periparturient period. Am. J. Vet. Res. 50:215-220.

Kehrli, M. E., B. J. Nonnecke, and J. A. Roth. 1989b. Alterations in bovine neutrophil function during the periparturient period. Am. J. Vet. Res. 50:207-214.

Kiku, Y., T. Ozawa, S. Kushibiki, M. Sudo, K. Kitazaki, N. Abe, H. Takahashi, and T. Hayashi. 2010. Decrease in bovine CD14 positive cells in colostrum is associated with the incidence of mastitis after calving. Vet. Res. Commun. 34:197-203.

Lacetera, N., D. Scalia, U. Bernabucci, B. Ronchi, D. Pirazzi, and A. Nardone. 2005. Lymphocyte functions in overconditioned cows around parturition. J. Dairy Sci. 88:2010-2016.

Lacetera, N., D. Scalia, O. Franci, U. Bernabucci, B. Ronchi, and A. Nardone. 2004. Effects of non-esterified fatty acids on lymphocyte function in dairy heifers. J. Dairy Sci. 87:1012-1014.

Liebler-Tenorio, E. M., G. Riedel-Caspari, and J. F. Pohlenz. 2002. Uptake of colostral leukocytes in the intestinal tract of newborn calves. Vet. Immunol. Immunopathol. 85:33-40.

Meganck, V., B. M. Goddeeris, E. Stuyven, S. Piepers, E. Cox, and G. Opsomer. 2014. Development of a method for isolating bovine colostrum mononuclear leukocytes for phenotyping and functional studies. Vet. J. 200:294-298.

Moore, M., J. W. Tyler, M. Chigerwe, M. E. Dawes, and J. R. Middleton. 2005. Effect of delayed colostrum collection on colostral IgG concentration in dairy cows. J. Am. Vet. Med. Assoc. 226:13751377.

Morin, D. E., S. V. Nelson, E. D. Reid, D. W. Nagy, G. E. Dahl, and P. D. Constable. 2010. Effect of colostral volume, interval between calving and first milking, and photoperiod on colostral IgG concentrations in dairy cows. J. Am. Vet. Med. Assoc. 237:420-428.

Nickerson, S. C. 1989. Immunological aspects of mammary involution. J. Dairy Sci. 72:1665-1678.

Nonnecke, B. J., and J. A. Harp. 1985. Effect of chronic staphylococcal mastitis on mitogenic responses of bovine lymphocytes. J. Dairy Sci. 68:3323-3328.

Nonnecke, B. J., and M. E. Kehrli. 1985. Isolation of mononuclear cells from bovine milk by continuous-flow and density gradient centrifugation: response of cells to mitogens. Am. J. Vet. Res. 46:1259-1262.

Ohtsuka, H., S. Terasawa, C. Watanabe, M. Kohiruimaki, M. Mukai, T. Andro, K. R. Petrovski, and S. Morris. 2010. Effect of parity on 
lymphocytes in peripheral blood and colostrum of healthy Holstein dairy cows. Can. J. Vet. Res. 74:130-135.

Opsomer, G., D. Hoeben, A. de Kruif, and C. Burvenich. 1998. The relationship between energy parameters and the respiratory burst activity of neutrophils in the blood of high yielding dairy cows during the periparturient period. In Proc. 10th Int. Conf. Prod. Dis. Farm Anim., Vol 67 Utrecht, the Netherlands.

Park, Y. H., L. K. Fox, M. J. Hamilton, and W. C. Davis. 1992. Bovine mononuclear leukocyte subpopulations in peripheral blood and mammary gland secretions during lactation. J. Dairy Sci. 75:998-1006.

Park, Y. H., L. K. Fox, M. J. Hamilton, and W. C. Davis. 1993. Suppression of proliferative response of BoCD4+ T lymphocytes by activated BoCD8+ T lymphocytes in the mammary gland of cows with Staphylococcus aureus mastitis. Vet. Immunol. Immunopathol. 36:137-151.

Parmely, M. J., A. E. Beer, and R. E. Billingham. 1976. In vitro studies on the T-lymphocyte population of human milk. J. Exp. Med. 144:358-370.

Parmely, M. J., D. B. Reath, A. E. Beer, and R. E. Billingham. 1977. Cellular immune responses of human milk $\mathrm{T}$ lymphocytes to certain environmental antigens. Transplant. Proc. 9:1477-1483.

Prescott, S. C., and R. S. Breed. 1910. The determination of the number of body cells in milk by a direct method. J. Infect. Dis. 7:632-640.

Reber, A. J., A. R. Hippen, and D. J. Hurley. 2005. Effects of the ingestion of whole colostrum or cell-free colostrum on the capacity of leukocytes in newborn calves to stimulate or respond in one-way mixed leukocyte cultures. Am. J. Vet. Res. 66:1854-1860.

Reber, A. J., A. Lockwood, A. R. Hippen, and D. J. Hurley. 2006. Colostrum induced phenotypic and trafficking changes in maternal mononuclear cells in a peripheral blood leukocyte model for study of leukocyte transfer to the neonatal calf. Vet. Immunol. Immunopathol. 109:139-150.

Riedel-Caspari, G. 1993. The influence of colostral leukocytes on the course of an experimental Escherichia coli infection and serum antibodies in neonatal calves. Vet. Immunol. Immunopathol. 35:275-288.

Riedel-Caspari, G., and F. W. Schmidt. 1991. The influence of colostral leukocytes on the immune system of the neonatal calf. III. Effects on phagocytosis. Dtsch. Tierarztl. Wochenschr. 98:330-334.
Shafer-Weaver, K. A., G. M. Pighetti, and L. M. Sordillo. 1996. Diminished mammary gland lymphocyte functions parallel shifts in trafficking patterns during the postpartum period. Proc. Soc. Exp. Biol. Med. 212:271-280.

Smith, C. W., and A. S. Goldman. 1968. The cells of human colostrum. I. In vitro studies of morphology and functions. Pediatr. Res. 2:103-109.

Sugisawa, H., T. Itou, and T. Sakai. 2001. Promoting effect of colostrum on the phagocytic activity of bovine polymorphonuclear leukocytes in vitro. Biol. Neonate 79:140-144.

Taylor, B. C., J. D. Dellinger, J. S. Cullor, and J. L. Stott. 1994. Bovine milk lymphocytes display the phenotype of memory $\mathrm{T}$ cells and are predominantly CD8+. Cell. Immunol. 156:245-253.

Thanasak, J., K. E. Muller, S. J. Dieleman, A. Hoek, J. Noordhuizen, and V. Rutten. 2005. Effects of polyunsaturated fatty acids on the proliferation of mitogen stimulated bovine peripheral blood mononuclear cells. Vet. Immunol. Immunopathol. 104:289-295.

Tyler, J. W., B. J. Steevens, D. E. Hostetler, J. M. Holle, and J. L. Denbigh. 1999. Colostral immunoglobulin concentrations in Holstein and Guernsey cows. Am. J. Vet. Res. 60:1136-1139.

Van Kampen, C., B. A. Mallard, and B. N. Wilkie. 1999. Adhesion molecules and lymphocyte subsets in milk and blood of periparturient Holstein cows. Vet. Immunol. Immunopathol. 69:23-32.

Wirt, D. P., L. T. Adkins, K. H. Palkowetz, F. C. Schmalstieg, and A. S. Goldman. 1992. Activated and memory T lymphocytes in human milk. Cytometry 13:282-290.

Wood, L. G., H. A. Scott, M. L. Garg, and P. G. Gibson. 2009. Innate immune mechanisms linking non-esterified fatty acids and respiratory disease. Prog. Lipid Res. 48:27-43.

Wuryastuti, H., H. D. Stowe, R. W. Bull, and E. R. Miller. 1993. Effects of vitamin $\mathrm{E}$ and selenium on immune responses of peripheral blood, colostrum, and milk leukocytes of sows. J. Anim. Sci. 71:2464-2472.

Yang, T. J., I. A. Ayoub, and M. J. Rewinski. 1997. Lactation stagedependent changes of lymphocyte subpopulations in mammary secretions: Inversion of $\mathrm{CD} 4+/ \mathrm{CD} 8+\mathrm{T}$ cell ratios at parturition. Am. J. Reprod. Immunol. 37:378-383. 